\title{
Chemotherapeutic Efficacy of Indigofera aspalathoides on 20-Methylcholanthrene-Induced Fibrosarcoma in Rats
}

\author{
Selva Kumar Sivagnanam, ${ }^{1}$ Mudiganti Ram Krishna Rao, ${ }^{1}$ and \\ Maruthaiveeran Periyasamy Balasubramanian' \\ ${ }^{1}$ Department of Industrial Biotechnology, Bharath University, Chennai 600073, India \\ ${ }^{2}$ Department of Pharmacology and Environmental Toxicology, Dr. ALM Post Graduate Institute of Basic Medical Sciences, \\ University of Madras, Tharamani, Chennai 600113, India
}

Correspondence should be addressed to Selva Kumar Sivagnanam, selvakumarmss@gmail.com

Received 7 November 2011; Accepted 7 December 2011

Academic Editor: B.-N. Wu

Copyright (C) 2012 Selva Kumar Sivagnanam et al. This is an open access article distributed under the Creative Commons Attribution License, which permits unrestricted use, distribution, and reproduction in any medium, provided the original work is properly cited.

\begin{abstract}
The present study was undertaken to test the chemopreventive effects of one herbal medicinal plant, Indigofera aspalathoides, on chemically induced carcinogenesis in rats. A well-known polyaromatic hydrocarbon, namely, 20-methylcholanthrene, which is a known carcinogenic substance, was used to induce fibrosarcoma in Wistar strain of male albino rats. Fibrosarcoma rats were treated with aqueous extracts of Indigofera aspalathoides. The rats were divided into four groups, each consisting of six animals. Group I served as normal control, Group II served as fibrosarcoma-induced animals, Group III were fibrosarcoma-bearing animals treated with aqueous extracts of Indigofera aspalathoides, and Group IV animals, which were normal healthy animals treated with Indigofera aspalathoides aqueous extract, served as drug control set. Group III and Group IV animals were treated with aqueous extract of Indigofera aspalathoides intraperitoneally at a dose of $250 \mathrm{mg} / \mathrm{kg}$. b.w. for 30 days. The fibrosarcoma was proved by pathological examinations. The activity levels of nucleic acids such as total DNA and RNA and hexose, hexosamine, and sialic acid in liver and kidney of treated rats were used to monitor the chemopreventive role of the plant extract. The observed increase in the levels of DNA, RNA, hexose, hexosamine, and sialic acid in liver and kidney tissues of fibrosarcoma-bearing animals reached near normal state after the treatment with aqueous extracts of Indigofera aspalathoides, suggesting that Indigofera aspalathoides does have a chemotherapeutic role.
\end{abstract}

\section{Introduction}

The disease cancer will become the leading cause of mortality among human population [1]. Chemical carcinogenesis due to a number of agents is a proven fact. Over $67 \%$ of cancers are presently attributed to environmental factors of which chemicals occupy a predominant proportion [2]. Consistent evidence shows carcinogenesis to be caused by certain chemicals such as polycyclic aromatic hydrocarbons $(\mathrm{PAH})$ like 20-methylcholanthrene or 3-methylcholanthrene. They are readily detected in the air we breathe or the tobacco that we smoke [3]. 20-Methylcholanthrene (20-MCA) causes a wide range of tumors in all animal models.

The specific type of cancer produced varies with the root of administration and include, tumors of the skin, soft tissues, and breast. PAHs are metabolized by cytochrome
$\mathrm{P}_{450}$-dependent mixed-function oxidases to give electrophilic epoxides. The epoxides either get detoxified or bind covalently to the DNA. The resultant abnormal DNA induces abnormal cell division and produce malignancy [3]. 20-MCA has been extensively used as an effective experimental model in the field of carcinogenesis.

Carcinogenesis is a multistage disease process. The events leading to cancer is sequential, involving both intrinsic and extrinsic factors. At the molecular level, cancer is caused by abnormal gene expression. This occurs through a number of mechanisms including a direct damage to DNA leading to abnormal transcription of genome. Majority of chemical carcinogens cause mutations presumably in critical genes and alter the cell growth and differentiation through epigenetic factors. The development of fully malignant tumor 
is to involve the activation of altered expression of protooncogenes to oncogenes and the loss or inactivation of tumor suppression gene, the function of which is to control normal cellular activity [4]. In the present study, 20-MCA was used as a fibrosarcoma inducing agent in rats. Fibrosarcoma is a tumor composed of collagen fibers forming mesenchymal cells of fibroblasts and they arise from subcutaneous fibrous tissues [5]. The tumor is a large, firm, and pale mass without any capsule and infiltrates into the surrounding tissues. The tumor occurs near fibrous tissues and mostly in the region of thigh and knee.

Most patients present with a solitary palpable mass ranging from 3 to $8 \mathrm{~cm}$ in the greatest dimension. The peak age for fibrosarcoma incidence is 30 to 55 years. Most studies have reported a slightly higher incidence of this tumor in men than in women [6]. Fibrosarcomas are assigned grades, from 1 to 3 , the higher grade sarcomas (grade 2 or 3 ) pose a significant threat and present problems in local control [7]. Histological grading of fibrosarcoma is mainly based on the degree of cellularity, degree of cellular differentiation, number of mitotic figures, the amount of collagen produced by the tumor cells, and the extent of necrosis.

It is a fact that both surgery and radiotherapy may fail to cure cancer chiefly because the tumors might have already decimated to other parts of the body. For this reason, chemotherapy is considered as one of the best alternative.

Chemotherapy, although being a major treatment modality used in the control of advanced stages of malignancies, exhibits severe toxicity on normal tissues [8]. Plant products which have antioxidant and anticancer properties could be considered as good chemopreventive agents. Recent researches revolve around the urgency to evolve suitable chemotherapy with less or no toxic side effects.

Plants have played a major role in treatment of various diseases of animals and humans since time immemorial. More than $50 \%$ of all modern drugs are of natural origin and many of which have the ability to control and cure cancer [9]. A large number of active principles from traditional medicinal plants have been reported to have chemopreventive properties [10]. Most of the studies on chemoprevention are based on individual chemicals with well-defined mechanisms. Since carcinogenesis is a multifactorial and multistage process, the individual active compounds or active principles may not always be effective to control all the stages and, therefore, it is of interest to investigate the chemopreventive effect of crude extracts of plants which might control the different stages of cancer etiology as compounds like saponins, tannins, steroids, alkaloids present therein might act holistically to effect a proper cure for cancer.

The plant Indigofera aspalathoides is used as a potent drug for many diseases in the traditional Indian system. This plant belongs to the family Papilionaceae and it is commonly known as Sivanar Vembu or Iraivanar Vembu in Tamil language of India. The leaves, flowers, and tender shoots are said to be cooling and demulcent [11].This plant is used for the treatment of leprosy, syphilis, and various skin diseases [12]. The plant mainly contains saponins, tannins, steroids, alkaloids, flavonoids, and reducing sugars. The present study was aimed at finding out the curative role of the aqueous extract of Indigofera aspalathoides on 20-MCAinduced fibrosarcoma in rats. Some reports of its anticancer and antioxidant properties are already been studied by us [13-16]. The present study is to further know this plant's chemopreventive role on some more parameters like total DNA and RNA content and on parameters like hexose, hexosamine, and sialic acid.

\section{Materials and Methods}

2.1. Plant Materials. Resh aerial parts (leaves, stems, and seeds) of the plant Indigofera aspalathoides were obtained and authenticated by the Chief Botanist, Tamil Nadu Aromatic and Medicinal Plants Corporation Limited (TAMPCOL) at Government Siddha Medical College Campus, Arumbakkam, Chennai, India in 2001.

2.2. Preparation of Plant Extract. $1 \mathrm{~kg}$. of the shade dried and coarsely powdered aerial parts of the plant Indigofera aspalathoides was charged in an aspiration bottle and allowed to soak in double distilled water for $48 \mathrm{hrs}$ at room temperature. The extract was filtered and concentrated on a water bath. The inorganic material was precipitated and filtered off. The filtrate was again concentrated in a China dish and dried in vacuum. The yield of the extract was $10 \% \mathrm{w} / \mathrm{w}$ of the powdered aqueous extract. This was stored in refrigerator for further and future use.

2.3. Acute Toxicity Studies. Acute toxicity study of AEIA (acute toxicity of Indigofera aspalathoides) was done as per OECD guideline 425 , using albino male rats. The animals was kept fasting overnight providing only with water, after which the extract was administered orally for one animal at the limit dose of $2500 \mathrm{mg} \mathrm{kg}^{-1}$ and observed for 14 days ( special attention for the first $4 \mathrm{hrs}$ of administration followed by the next $20 \mathrm{hrs}$ ). In case of the death, the limit test was terminated and main test was conducted. If the animal survived, four additional animals were dosed sequentially so that five animals could be tested. However, if three animals died, the limit test was terminated and the main test was performed. The $\mathrm{LD}_{50}$ is greater than $2500 \mathrm{mg} \mathrm{kg}^{-1}$ if three or more animals survived. If an animal died unexpectedly late in the study and there were other survivors, it was appropriate to stop dosing and observing all animals to see if other animals also die during a similar observation period.

2.4. Acute Toxicity Test. The AEIA has not shown any mortality at the limit dose of $2500 \mathrm{mg} \mathrm{kg}^{-1}$ body weight. AEIA was found to be safe even at a higher concentration and, based on this, the dose for the chemopreventive activity was chosen.

2.5. Animals. Wistar strain male albino rats weighing 100 to $120 \mathrm{~g}$ were obtained from TANUVAS-LAMU, Madhavaram, Chennai, India. The animals were fed with normal pellet diet (rat chew) and water ad libitum. The study protocol, 
Histopathological studies in liver of control and experimental animals (H \& E 100x)

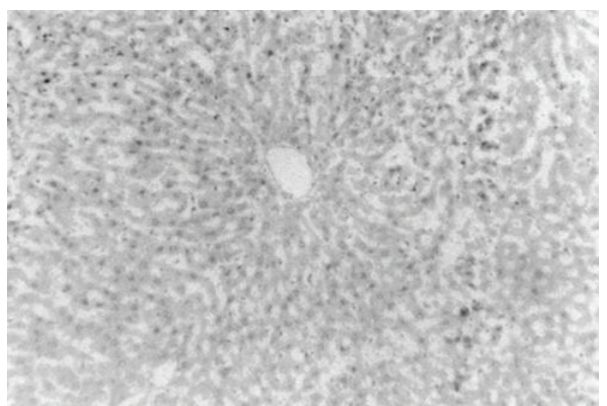

Group I control animals showing normal architecture

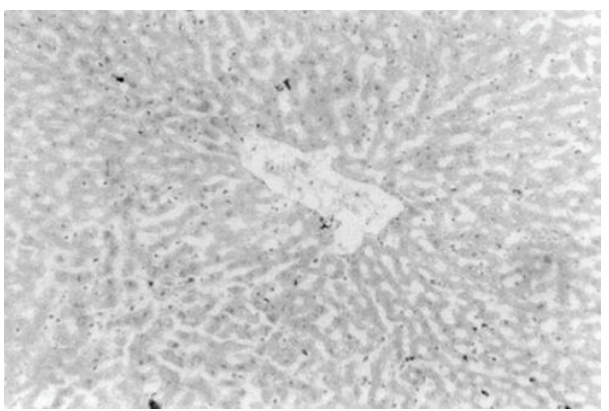

Group II fibrosarcoma-bearing animals showing mild congestion of sinusoids with central dilatation

(a)

Histopathological studies in liver of control and experimental animals (H \& E 100x)

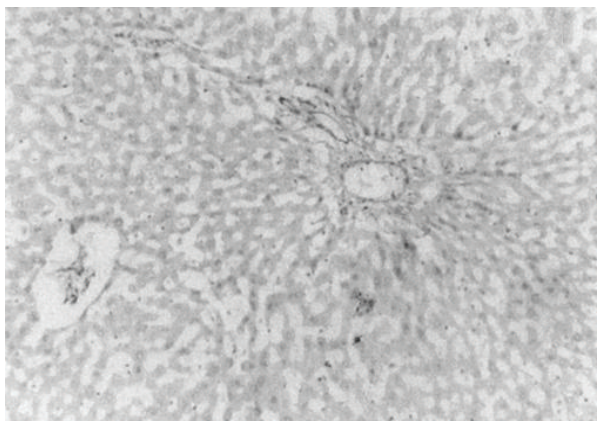

Group III fibrosarcoma-bearing animals treated with Indigofera aspalthoides showing mild congestion of sinusoids

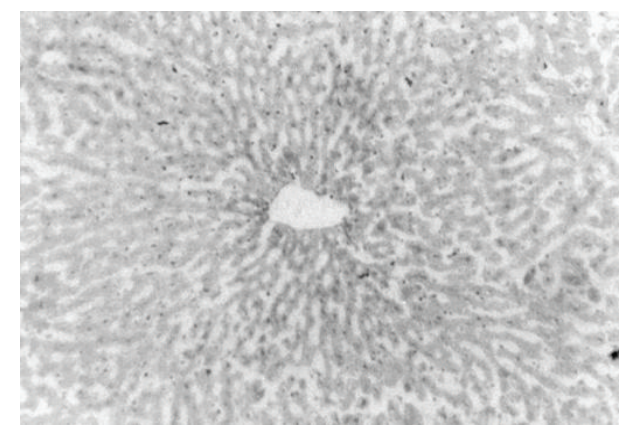

Group IV drug control animals treated with Indigofera aspalthoides showing normal architecture

(b)

FIGURE 1: The histopathological patterns in liver before and after treatment.

TABLe 1: The levels of nucleic acids in liver and kidney of control and experimental animals.

\begin{tabular}{|c|c|c|c|c|}
\hline $\begin{array}{l}\text { Parameters } \\
\text { (mg/gm.wt. of tissue) }\end{array}$ & $\begin{array}{l}\text { Group I } \\
\text { (control) }\end{array}$ & $\begin{array}{c}\text { Group II } \\
\text { (fibrosarcoma) }\end{array}$ & $\begin{array}{c}\text { Group III } \\
\text { (fibrosarcoma+ } \mathrm{I} \\
\text { aspalathoides) }\end{array}$ & $\begin{array}{l}\text { Group IV I. } \\
\text { aspalathoides }\end{array}$ \\
\hline \multicolumn{5}{|l|}{ Liver } \\
\hline DNA & $5.45 \pm 0.46$ & $6.54 \pm 0.25^{\mathrm{a} *}$ & $5.46 \pm 0.45^{\mathrm{aNSb} *}$ & $5.32 \pm 0.34^{\mathrm{aNS}}$ \\
\hline RNA & $7.58 \pm 0.27$ & $8.95 \pm 0.45^{\mathrm{a} *}$ & $7.72 \pm 0.29^{\mathrm{aNSb} *}$ & $4.38 \pm 0.22^{\mathrm{aNS}}$ \\
\hline \multicolumn{5}{|l|}{ Kidney } \\
\hline DNA & $4.42 \pm 2.1$ & $5.90 \pm 0.54^{\mathrm{a} *}$ & $4.48 \pm 0.29^{\mathrm{aNSb} *}$ & $4.38 \pm 0.22^{\mathrm{aNS}}$ \\
\hline RNA & $6.34 \pm 0.38$ & $7.99 \pm 0.36^{\mathrm{a} *}$ & $6.25 \pm 0.41^{\mathrm{aNSb} *}$ & $6.23 \pm 0.42^{\mathrm{aNS}}$ \\
\hline
\end{tabular}

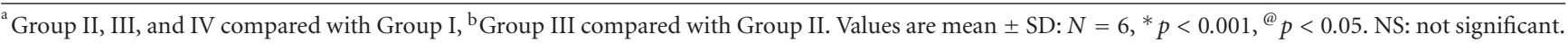

approved by the Ministry of Social Justice and Empowerment, Government of India, was followed (Institutional Animals Ethics Committee (IAEC) no. 07/15/02).

2.6. Sample Collection. The animals were sacrificed by cervical decapitation at the end of the experimental period and the liver and kidney were dissected out and known weight of liver and kidney were homogenized in $0.1 \mathrm{M}$ Tris- $\mathrm{HCl}$ buffer (pH-7.4). Animals were starved overnight before sacrifice.
2.7. Chemicals. All the chemicals and reagents used were purchased from M/s. Sigma Chemicals, USA.

2.8. Induction of Fibrosarcoma. Fibrosarcoma was induced in Wistar strain of male albino rats by subcutaneous implantation of Millipore filter disc, impregnated with 5\% suspension of 20-MCA in paraffin oil [17]. Tumors which appeared in about 4 weeks after implantation were highly localized and were maintained by serial transplantation. 
Histopathological studies in kidney of control and experimental animals ( $\mathrm{H} \& \mathrm{E} 100 \mathrm{x})$

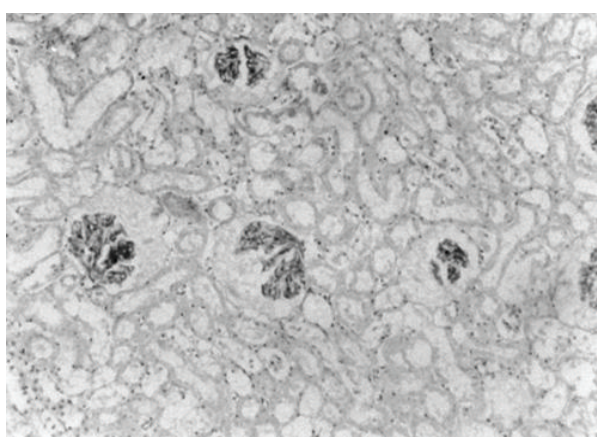

Group I control animals showing normal architecture

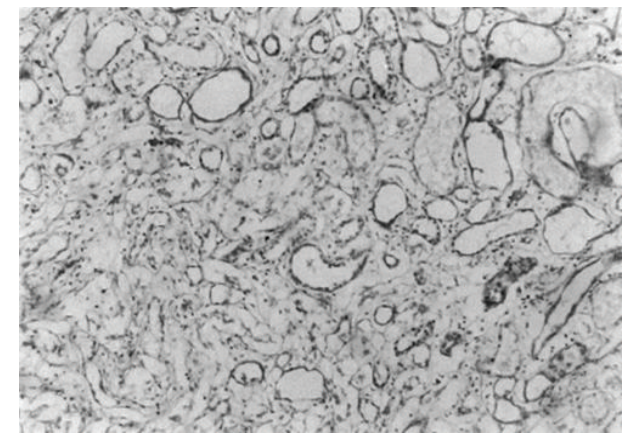

Group II fibrosarcoma-bearing

tubular dilation with congested vessels

(a)

Histopathological studies in kidney of control and experimental animals (H \& E 100x)

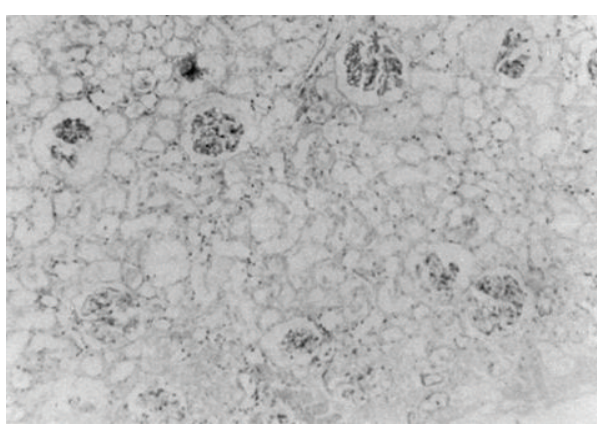

Group III fibrosarcoma-bearing animals treated with Indigofera aspalthoides showing normal architecture

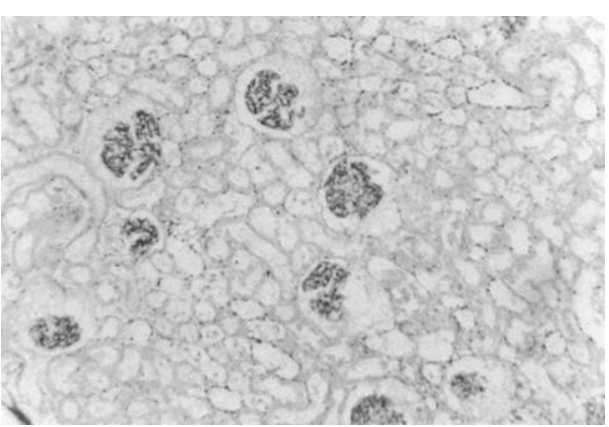

Group IV drug control animals treated with Indigofera aspalthoides showing normal architecture

(b)

FIgURE 2: The histopathological patterns in kidney before and after treatment.

The tumor was minced and suspended in normal saline. A suspension of about $1 \times 10^{6}$ cells in $0.5 \mathrm{~mL}$ of saline was injected subcutaneously, into the thigh. The transplanted tumor became palpable in 4-6 days time.

2.8.1. Histopathological Analysis. The liver and kidney of control and experimental animals were used for histopathological analysis. It was carried out in Department of Pathology, Madras Medical College, Chennai, India. Figures 1 and 2 show the architecture of both liver and kidney, respectively, before and after treatment on fibrosarcoma-bearing animals with Indigofera aspalathoides aqueous extract. From the figures, it is clear that the treatment of this drug has restored the liver and kidney architecture.

2.9. Experimental Design. The rats were divided into four different groups, each group consisting of six animals. Group I animals served as normal control, Group II animals were fibrosarcoma-bearing animals after the incubation period, Group III animals were fibrosarcoma-bearing animals treated with aqueous extract of Indigofera aspalathoides intraperitoneally at a dose of $250 \mathrm{mg} / \mathrm{kg}$ b. w. for 30 days, and Group IV animals which were administered with the aqueous extract of Indigofera aspalathoides alone, at a dose of $250 \mathrm{mg} / \mathrm{kg}$ b. w. for 30 days, served as drug control animals.

2.10. Tumor Measurements. Tumor measurements were made using a vernier calipers, and tumor diameter (Td) was calculated using the formula stated elsewhere. The experiments were repeated twice

$$
\begin{aligned}
& \text { Td }(\mathrm{cm}) \\
& =\frac{\text { Length of tumor }(\mathrm{cm})+\text { Width of tumor }(\mathrm{cm})}{2}
\end{aligned}
$$

2.11. Statistical Analysis. The statistical data was presented as the \pm standard deviation (SD). One-way analysis of variance (ANOVA), using SPSS 7.5 student version, was used for statistical significance between groups. The Tukey's multiple comparison method was used to compare the means of different groups and the significance was denoted by $P$ value.

2.12. Estimation of Nucleic Acids. A known amount of tissue was homogenized in $5 \mathrm{~mL}$ of ice cold distilled water using a Portor Elvehjem homogenizer with a Teflon pestle. $5 \mathrm{~mL}$ of $5 \%$ trichloroacetic acid was added to the homogenate 
TABLE 2: The levels of hexose, hexosamine, and sialic acid in liver and kidney of control and experimental animals.

\begin{tabular}{lcccc}
\hline $\begin{array}{l}\text { Parameters (mg/g. } \\
\text { defatted tissue) }\end{array}$ & $\begin{array}{l}\text { Group I } \\
\text { Control }\end{array}$ & $\begin{array}{c}\text { Group II } \\
\text { Fibrosarcoma }\end{array}$ & $\begin{array}{c}\text { Group III } \\
\text { Fibrosarcoma }+I . \\
\text { aspalathoides }\end{array}$ & $\begin{array}{c}\text { Group IV I. } \\
\text { aspalathoides }\end{array}$ \\
\hline Liver: hexose & $19.44 \pm 1.84$ & $31.89 \pm 2.72^{\mathrm{a} *}$ & $23.55 \pm 2.12^{\mathrm{a} \mathrm{b} *}$ & $20.91 \pm 1.66^{\mathrm{aNS}}$ \\
Hexosamine & $4.09 \pm 0.36$ & $8.86 \pm 0.92^{\mathrm{a} *}$ & $5.06 \pm 0.46^{\mathrm{a} * \mathrm{~b} *}$ & $4.70 \pm 0.32^{\mathrm{aNS}}$ \\
Sialic acid & $0.28 \pm 0.02$ & $0.76 \pm 0.08^{\mathrm{a} *}$ & $0.35 \pm 0.04^{\mathrm{a} @ \mathrm{~b} *}$ & $0.29 \pm 0.03^{\mathrm{aNs}}$ \\
Kidney: hexose & $18.84 \pm 1.50$ & $26.16 \pm 3.05^{\mathrm{a} *}$ & $20.18 \pm 2.11^{\mathrm{a} \mathrm{b} *}$ & $19.22 \pm 1.75^{\mathrm{aNS}}$ \\
Hexosamine & $2.17 \pm 0.17$ & $3.39 \pm 0.38^{\mathrm{a} *}$ & $2.62 \pm 0.20^{\mathrm{a} @ \mathrm{~b} *}$ & $2.27 \pm 0.16^{\mathrm{aNS}}$ \\
Sialic acid & $0.30 \pm 0.03$ & $0.55 \pm 0.07^{\mathrm{a} *}$ & $0.36 \pm 0.05^{\mathrm{aNSb} *}$ & $0.32 \pm 0.03^{\mathrm{aNS}}$ \\
\hline
\end{tabular}

${ }^{\mathrm{a}}$ Group II, III, and IV compared with Group I, ${ }^{\mathrm{b}}$ Group III compared with Group II. Values are mean \pm SD: $N=6,{ }^{*} p<0.001,{ }^{\circledR} p<0.05$, NS: not significant.

and this was kept in ice for 30 minute to allow complete precipitation of proteins. The mixture was centrifuged and the precipitate obtained was washed thrice with ice cold $10 \%$ TCA. Then it was treated with $95 \%$ ethanol to remove the lipids. The final precipitate was heated at $90^{\circ} \mathrm{C}$ for 15 minutes which facilitated the quantitative separation of nucleic acids from proteins. The supernatant after centrifugation was used for the estimation of DNA and RNA [18].

2.13. Estimation of DNA. The method of Burton 1956 [19] was followed for DNA estimation. A known volume of nucleic acid aliquot was made up to 3 mi with $1 \mathrm{~N}$ perchloric acid. This was mixed with $2 \mathrm{~mL}$ of diphenylamine reagent. This was kept in boiling water bath for 10 minutes and the blue colour developed was recorded at $640 \mathrm{~nm}$ in a spectrophotometer. A reagent blank and standards were also carried out. The values are expressed as $\mathrm{mg} / \mathrm{g}$ wet tissue.

2.14. Estimation of RNA. The estimation was carried out by the method of Rawal et al. 1977 [20]. Aliquot of nucleic acid was made up to $2 \mathrm{~mL}$ with $5 \%$ trichloroacetic acid. $3 \mathrm{~mL}$ of Orcinol-Ferric chloride reagent was added to this and mixed well. The tubes were heated in a water bath for 20 minutes. Reagent blanks and standards were also treated in the same way. The tubes were cooled and the colour developed was measured at $640 \mathrm{~nm}$ using a spectrophotometer. The values were expressed in $\mathrm{mg} / \mathrm{g}$ wet tissue.

2.15. Estimation of Hexose and Hexosamine and Sialic Acid. A known volume of delipidised tissue sample residue was mixed with $2 \mathrm{~mL}$ ethanol and left for 20 minutes and then centrifuged. $3 \mathrm{~mL}$ of $3 \mathrm{~N} \mathrm{HCL}$ was added to the precipitate and hydrolysed for 4 hours at $100^{\circ} \mathrm{C}$ in a water bath for the estimation of hexose and hexosamine by the method of Folsch, 1951 [21].

2.16. Estimation of Hexose. The method of Niebes, 1972 [22], was followed for estimating hexose. To $0.5 \mathrm{~mL}$ of neutrilised sample, $7 \mathrm{~mL}$ Orcinol reagent was added very slowly to the tubes keeping them in ice water bath. The contents were mixed well and the tubes were heated at $80^{\circ} \mathrm{C}$ for 15 minutes. After cooling the dark colour developed was read at $540 \mathrm{~nm}$ using a spectrophotometer. The standard consisted of 25 to $100 \mu \mathrm{g}$ of hexose and the blank containing $0.5 \mathrm{~mL}$ of water instead of the sample was also treated in the same way. The Hexose content was expressed as $\mathrm{mg} / \mathrm{g}$ of defatted tissue for liver and kidney.

2.17. Estimation of Hexosamine. The level of Hexosamine was assayed by the method of Wagner, 1979 [23]. $0.5 \mathrm{~mL}$ of the neutralized sample was made up to $1 \mathrm{~mL}$ with water. Standard galactosamine was made up to $1 \mathrm{~mL}$. The blank comprised of $1 \mathrm{~mL}$ of water. $0.6 \mathrm{~mL}$ of acetyl-acetone reagent was added to all the tubes and heated in a boiling water bath for 30 minutes. After cooling, $2 \mathrm{~mL}$ of Ehrlich reagent was added and the contents were shaken well. The pink colour developed was read at $540 \mathrm{~nm}$ against blank. The Hexosamine content was expressed in $\mathrm{mg} / \mathrm{g}$ of defatted tissues of liver and kidney.

2.18. Estimation of Sialic Acid. The method of Warren, 1959 [24], was used to estimate sialic acid. A known amount of delipidised residue of the tissue was hydrolysed with $1 \mathrm{~mL}$ of $0.1 \mathrm{~N}$ sulphuric acid at $80^{\circ} \mathrm{C}$ for one hour. The hydrolysed materials were neutralized and used for estimation of sialic acid. To $0.5 \mathrm{~mL}$ of neutralized sample, $0.25 \mathrm{~mL}$ of Periodate was added and incubated at $37^{\circ} \mathrm{C}$ for 30 minutes. After the incubation, the reaction was arrested by the addition of $0.25 \mathrm{~mL}$ of Arsenite. The tubes were shaken well. $2 \mathrm{~mL}$ of TBA was added and the tubes were heated for 6 minutes in water bath. $5 \mathrm{~mL}$ of acidified butanol was added to the tubes after cooling and shaken well. Once settled, the butanol phase was separated. The absorbance for colour was read at $540 \mathrm{~nm}$ against a blank. Standard $\mathrm{N}$-acetylneuraminic acid was also treated similarly. Sialic acid content was expressed as $\mathrm{mg} / \mathrm{mL}$ of defatted tissue for liver and kidney.

\section{Results and Discussion}

Table 1 depicts the levels of nucleic acid, DNA, and RNA in the liver and kidney of control and experimental animals. Elevated levels of DNA and RNA were observed in Group II animals as compared to normal control, Group I animals. In the fibrosarcoma-bearing Indigofera-aspalathoides-treated Group III animals, the DNA and RNA levels reached near normal levels. No significant alteration occurred in the values of DNA and RNA in Group IV animals which were treated with the plant extract alone as compared with the 
normal Group I animals. The lack of difference in the results in Group IV and Group I normal control animals clearly demonstrates that Indigofera aspalathoides extracts do not have any toxic side effects which justifies the choice of this drug. Nucleic acids play a vital role during neoplastic transformation.

DNA and RNA contents were studied in order to determine the effects of Indigofera aspalathoides on macromolecular synthesis in fibrosarcoma. It has been observed that the tumor growth corresponds with the elevated levels of DNA and RNA synthesis in the liver and kidney. The levels of DNA and RNA progressively increased in fibrosarcoma animals. Among the two, DNA increase was much prominent compared to RNA content. But after the treatment with Indigofera aspalathoides, there was a marked decrease in the content of these two nucleic acids suggesting that the plant extract might have controlled their biosynthesis indicating the tumoricidal effect during cancer therapy.

Table 2 depicts the levels of hexose, hexosamine, and sialic acid in liver and kidney of control and experimental animals. In Group II fibrosarcoma-bearing animals, the levels of these three parameters in liver and kidney tissues were significantly elevated $(P<0.001)$ as compared to that of the control group animals. But in Group III drug-treated animals, these protein levels were reverted back to near normal condition as compared with Group II fibrosarcoma animals. No significant changes of these levels were observed in Group IV drug-alone-treated animals when compared to normal control group I animals.

Heidelberger, 1975 [25], has sited the reduced levels of proteins in neoplastic tissues. The liver is an important site of protein metabolism and it has the highest rate of protein synthesis. Major protein mass of the organism is severely affected in cancer cachexia. Protein waste implies the underlying metabolic imbalance which is being expressed by an elevation in the apparent protein degradation rate with no change in the apparent synthesis rate [26]. Reduced liver protein in Moris-hepatoma-bearing animals, in Walker 256 carcinoma, and in some other reports suggests increased protein degradation [27]. There is decrease in the recycling of amino acids in tumor conditions resulting in enhanced efflux of these amino acids from the tissues. Thus the host response to the tumor load results in tissue protein breakdown. Treatment with Indigofera aspalathoides might have prevented this protein breakdown thus bringing the protein levels to near normal condition.

The crucial role of cell surface and cell membrane constituents in neoplastic behaviours and the changes in serum and tissue glycoconjugates have long been associated with malignancies [28]. Abnormal increase in the level of plasma protein components has been related to the changes in hepatic cells during neoplastic transformation. Mecbeth and Bakesi, 1994 [29], postulated that the presence of tumor in hepatic cells induces the synthesis of glycoproteins, which subsequently appear in circulation. Large amounts of hexose, hexosamnine, and sialic acids were reported in many cancer conditions [30].

Sialic acid is acetylated derivative of neuraminic acid and exists as terminal component of nonreducing end of carbohydrate chains of glycoprotein. Levels of sialic acid can be useful in early detection of cancer indicating progress of the disease, degree of metastasis, and possible recurrence [31]. Increased activity of sialyltransferase leads to an increased expression of sialic acid in cancer conditions. The influence of sialic acid on the oncogenicity of tumor cells has been studied by many investigators as the main determinant of the cell surface negative charge electromobility and the loss of contact inhibition. It also acts as an antigen-masking agent and as component of cell surface involved in the adherence of tumor cells to mesothelial membrane to form metastasis [32]. The reversal of glycoprotein levels to almost normal after the treatment of Indigofera aspalathoides may be due to its potent antitumor activity. The plant extract may alter cell membrane glycoprotein synthesis and structure. Thus the aqueous extract of Indigofera aspalathoides shows strong anticancer potency.

\section{References}

[1] J. Gibbs, "Mechanism-based target identification and drug discovery in cancer research," Science, vol. 287, no. 5460, pp. 1969-1973, 2000.

[2] P. Lichtenstein, N. V. Holm, P. K. Verkasalo et al., "Environmental and heritable factors in the causation of cancer: analyses of cohorts of twins from Sweden, Denmark, and Finland," The New England Journal of Medicine, vol. 343, no. 2, pp. 78-85, 2000.

[3] IARC (International Agency for Research on Cancer), Monographs on the Evaluation of Carcinogenic Risk of Chemicals to Man, vol. 3, Certain Polycyclic Hydrocarbons and Heterocyclic Compounds, Lyon, France, 1973.

[4] E. R. Fearon and B. Vogelstein, "A genetic model for colorectal tumorigenesis," Cell, vol. 61, no. 5, pp. 759-767, 1990.

[5] A. P. Stout Fibrosarcoma, "The malignant tumor of fibrosis," Cancer, vol. 1, pp. 30-36, 1948.

[6] A. Kathaleen and M. D. Havlin, "Sarcomas of soft tissue and bon," in Clinical Oncology, Appleton and Lange, G. R. Weiss, Ed., pp. 264-266, Connecticut, Conn, USA, 1993.

[7] J. Costa, R. A. Wesley, E. Glatstein, and S. A. Rosenberg, "The grading of soft tissue sarcomas. Results of a clinicohistopathologic correlation in a series of 163 cases," Cancer, vol. 53, no. 3, pp. 530-541, 1984.

[8] G. Pandey and S. Madhuri, "Medicinal plants: better remedy for neoplasm," Indian Drugs, vol. 43, no. 11, pp. 869-874, 2006.

[9] G. Raosangkima and S. B. Prasad, "Antitumor activity of some plants from Meghalaya and Mizoram against murine acites Dolton's lymphoma," Indian Journal of Experimental Biology, vol. 42, pp. 981-988, 2004.

[10] Y. Cai, Q. Luo, M. Sun, and H. Corke, "Antioxidant activity and phenolic compounds of 112 traditional Chinese medicinal plants associated with anticancer," Life Sciences, vol. 74, no. 17, pp. 2157-2184, 2004.

[11] K. R. Kirtikar and B. D. Basu, Illustrated Indian Medicinal Plants III, vol. 3, 2000, Revised and Enlarged Edition.

[12] R. Bhuvaneswari and C. Balasundaram, "Traditional Indian herbal extracts used in vitro against growth of the pathogenic bacteria Aeromonas hydrophila," Israeli Journal of Aquaculture, vol. 58, no. 2, pp. 89-96, 2006. 
[13] S. Selva Kumar, C. M. Karrunakaran, M. Ram Krishna Rao, and M. P. Balasubramanian, "Indigofra aspalathoides protectionagainst $20 \mathrm{MCA}$ induced experimental fibrosarcoma growth after tansplantation in rats: role of xenobiotic drug metabolizing enzymes," The Asian Pacific Journal of Cancer Prevention, vol. 11, pp. 1833-1837, 2010.

[14] S. S. Kumar, C. M. Karrunakaran, M. R. K. Rao, and M. P. Balasubramanian, "Inhibitory effects of Indigofera aspalathoides on 20-methylcholanthrene-induced chemical carcinogenesis in rats," Journal of Carcinogenesis, vol. 10, p. 1, 2011.

[15] S. Selva Kumar, M. Ram Krishna Rao, and M. P. Balasubramanian, "Chemopreventive effects of Indigofera aspalathoides on 20-MCA induced fibrosarcoma In rats," International Journal of Cancer Research, vol. 7, no. 2, pp. 144-151, 2011.

[16] S. S. Kumar, M. R. K. Rao, M. P. Balasubramanian et al., "Anticancer effects of Indigofera aspalathoides on 20methylcholanthrene induced fibrosarcoma in rats," Research Journal of Medicinal Plant, vol. 5, no. 6, pp. 747-755, 2011.

[17] B. Nagarajan and S. Sankaran, "Rapid method for the production of fibrosarcoma in rats and the effect of BCG administration," Indian Journal of Cancer, vol. 10, no. 1, pp. 83-84, 1973.

[18] W. C. Schneider, "Determination of nucleic acid in tissue," in Methods in Enzymology, S. P. Colowick and N. O. Kaplan, Eds., vol. 3, pp. 680-684, Academic Press, New York, NY, USA, 1957.

[19] K. Burton, "A study of the conditions and mechanism of the diphenylamine reaction for the colorimetric estimation of deoxyribonucleic acid," The Biochemical Journal, vol. 62, no. 2 , pp. 315-323, 1956.

[20] V. M. Rawal, V. S. Patel, G. N. Rao, and R. R. Desai, "Chemical and biochemical studies on cataractous human lenses IIIquantitative study of proteins, RNA and DNA," Arogya a Journal of Health Sciences, vol. 3, pp. 69-75, 1977.

[21] J. Folsch, M. Less, and G. H. S. Stanley, "A simple method for the isolation and purification of total lipides from animal tissues," The Journal of Biological Chemistry, vol. 226, no. 1, pp. 497-509, 1957.

[22] P. Niebes, "Determination of enzymes and degradation products of glycosaminoglycan. Metabolism in the serum of healthy and varicose subjects," Clinica Chimica Acta, vol. 42, no. 2, pp. 399-408, 1972.

[23] W. D. Wagner, "A more sensitive assay discriminating galactosamine and glucosamine in mixtures," Analytical Biochemistry, vol. 94, no. 2, pp. 394-396, 1979.

[24] L. Warren, "The thiobarbituric acid assay of sialic acids," The Journal of Biological Chemistry, vol. 234, no. 8, pp. 1971-1975, 1959.

[25] C. Heidelberg, "Chemical carcinogenesis," Annual Review of Biochemistry, vol. 44, pp. 79-121, 1975.

[26] L. Tessitore, G. Bonelli, and F. M. Baccino, "Early development of protein metabolic perturbations in the liver and skeletal muscle of tumour-bearing rats. A model system for cancer cachexia," Biochemical Journal, vol. 241, no. 1, pp. 153-159, 1987.

[27] A. M. Landel, W. G. Hammond, and M. M. Meguid, "Aspects of amino acid and protein metabolism in cancer-bearing states," Cancer, vol. 55, no. 1, pp. 230-237, 1985.

[28] P. S. Patel, B. R. Baxi, S. G. Adhavaryu, and D. B. Balan, "Individual and combined usefulness of lipid associated salic acid, mucoid proteins and hexoses as tumor markers in breast carcinoma," Cancer Letters, vol. 51, pp. 203-208, 1990.

[29] R. A. L. Mecbeth and J. G. Bekesi, "Plama glycoproteins in malignant disesase," AMA Archives of Surgery, vol. 88, pp. 627$632,1964$.
[30] S. Shimizu and I. Funakoshi, "Carbohydrate composition of the plasma membranes of rat ascites hepatoma," Biochimica et Biophysica Acta, vol. 203, no. 1, pp. 167-169, 1970.

[31] V. Shanmugam and B. Nagarajan, "Changes in sialic acid content in serum lipoprotein fractions of cancer patients," Arogya Journal of Health Sciences, vol. 11, pp. 69-70, 1985.

[32] S. B. Prasad, "Studies on the sialic acid in the tumor and normal cells using cisplatin as a probe," Current Science, vol. 55, pp. 651-655, 1986. 

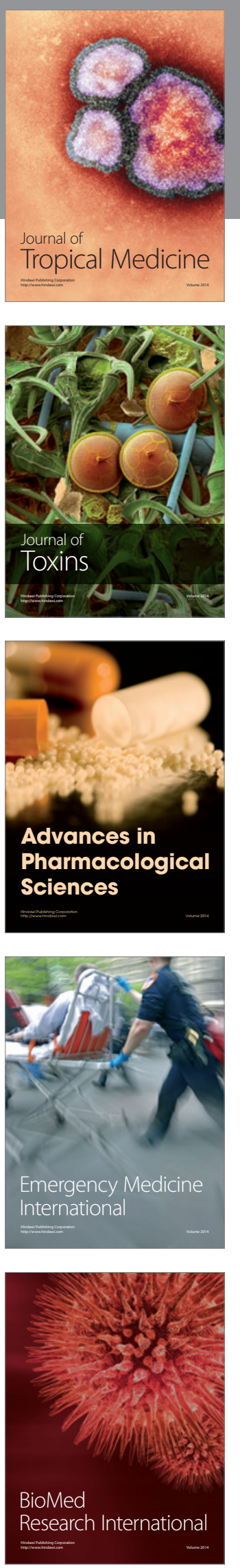
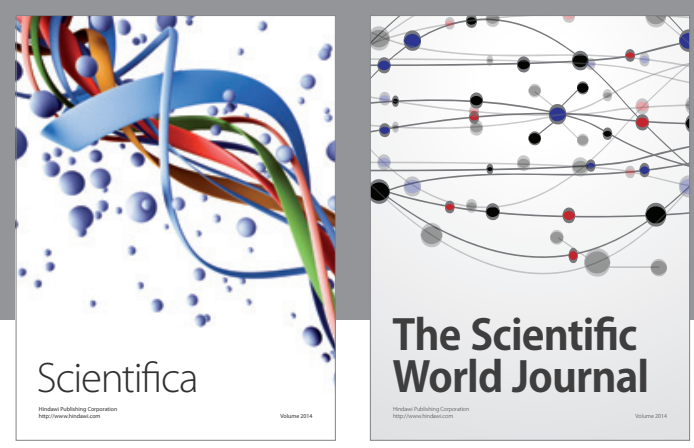

The Scientific World Journal
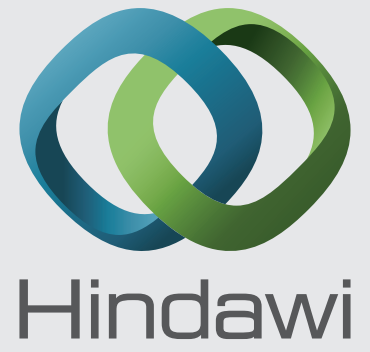

Submit your manuscripts at

http://www.hindawi.com
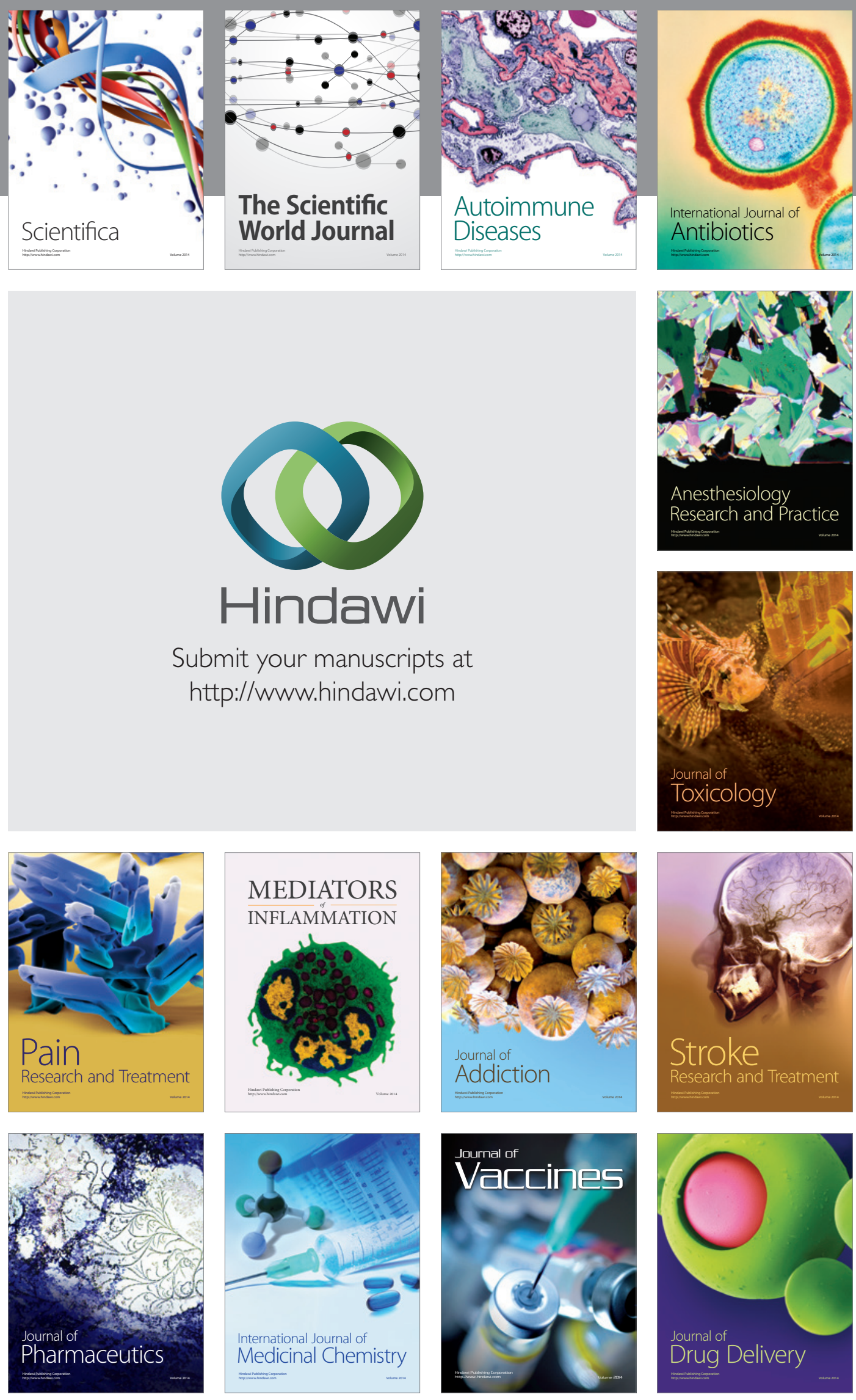